NBER WORKING PAPER SERIES

\title{
ASSESSING JOB FLOWS ACROSS COUNTRIES: THE ROLE OF INDUSTRY, FIRM SIZE AND REGULATIONS
}

\author{
John Haltiwanger \\ Stefano Scarpetta \\ Helena Schweiger \\ Working Paper 13920 \\ http://www.nber.org/papers/w13920
NATIONAL BUREAU OF ECONOMIC RESEARCH
1050 Massachusetts Avenue
Cambridge, MA 02138
April 2008

We are grateful to Robin Burgess, Laurence Kahn, Adriana Kugler, Julian Messina, Carmen Pages, John Shea, John Sutton, Luis Serven, James Tybout and the participants at the World Bank Conference on the 'Microeconomic of Growth' (Washington, D.C., May 18-19, 2006), at the Annual Conference of the European Association of Labour Economists (EALE, Prague, September 21-23, 2006), at the World Bank and IZA 2nd Conference on 'Employment and Development' (Bonn, June 8-9, 2007) and at the 2008 Annual Meetings of the American Economic Association (New Orleans, 4-6 January, 2008) for their insightful comments. The views expressed in this paper are our own and do not necessarily represent those of the institutions of affiliation. The views expressed herein are those of the author(s) and do not necessarily reflect the views of the National Bureau of Economic Research.

NBER working papers are circulated for discussion and comment purposes. They have not been peerreviewed or been subject to the review by the NBER Board of Directors that accompanies official NBER publications.

(C) 2008 by John Haltiwanger, Stefano Scarpetta, and Helena Schweiger. All rights reserved. Short sections of text, not to exceed two paragraphs, may be quoted without explicit permission provided that full credit, including $\odot$ notice, is given to the source. 
Assessing Job Flows Across Countries: The Role of Industry, Firm Size and Regulations

John Haltiwanger, Stefano Scarpetta, and Helena Schweiger

NBER Working Paper No. 13920

April 2008

JEL No. J23,J53,K31

\begin{abstract}
$\underline{\text { ABSTRACT }}$
This paper analyzes job flows in a sample of 16 industrial and emerging economies over the past decade, exploiting a harmonized firm-level dataset. It shows that industry and firm size effects (and especially firm size) account for a large fraction in the overall variability in job flows. However, large residual differences remain in the job flow patterns across countries. To account for the latter, the paper explores the role of differences in employment protection legislation across countries. Using a difference-in-difference approach that minimizes possible endogeneity and omitted variable problems, our findings show that hiring and firing costs tend to curb job flows, particularly in those industries and firm size classes that require more frequent labor adjustment.
\end{abstract}

John Haltiwanger

Department of Economics

University of Maryland

College Park, MD 20742

and NBER

haltiwan@econ.umd.edu

Stefano Scarpetta

OECD

Directorate for Employment, Labour and Social Affairs

2, rue Andrè-Pascal

75775 Paris Cedex 16, France

stefano.scarpetta@ oecd.org
Helena Schweiger

EBRD, Office of the Chief Economist

One Exchange Square

London EC2A 2JN United Kingdom

helena.schweiger@gmail.com 


\section{Introduction}

Over the past decade, a growing body of evidence has accumulated suggesting that the reallocation of factors of production - including labor - plays a major role in driving productivity growth (see for example Olley and Pakes [1996], Griliches and Regev [1995], Foster et al. [2001], Foster et al. [2002] and Bartelsman et al. [2004]). New firms enter the market and create new jobs, while other unprofitable firms exit the market contributing to job destruction (see e.g. Sutton [1997], Pakes and Ericson [1998], Geroski [1995]). Incumbent firms are in a continuous process of adaptation in response to the development of new products and processes, the growth and decline in markets and changes in competitive forces (Davis and Haltiwanger [1999]). Market conditions and institutional factors play a major role in shaping the magnitude of job flows and their characteristics (Davis et al. [1996]). For example, smaller businesses are inherently more dynamic, in part because they tend to be young ventures and adjust through a learning-by-doing process (Dunne et al. [1988], Dunne et al. [1989]). In addition, some industries have inherently higher job flows than others in all countries, given the smaller size of their typical business and lower inherent entry costs (for example, Foster et al. [2002] report that job flows in the United States retail sector are 1.5 times higher than in the manufacturing sector).

Technological and market driven factors are coupled with a host of regulations in driving job flows. For example, regulations affecting start-up costs or bankruptcy procedures are likely to affect firm turnover and the associated labor mobility. Likewise, employment protection legislation may stifle labor reallocation by raising labor adjustment costs. Assessing the role of regulations in affecting job flows, over and above that played by technological and market-driven factors, is of great importance. While labor reallocation is indeed important to promote productivity growth, it is also painful for the affected workers, who face significant search and other adjustment costs (see for example Mortensen and Pissarides [1999a], Mortensen and Pissarides [1999b] and Caballero and Hammour [2000b]). Several models predict that labor regulations reduce gross job flows (e.g. Bertola [1992], Hopenhayn and Rogerson [1993], Koeniger and Prat [2007]), but the empirical evidence is still inconclusive. While several empirical papers find a negative effect of employment protection legislation on worker turnover (Bentolila and Bertola [1990], Nickell and Layard [1999]), the effects on job turnover are more nuanced (Bertola and Rogerson [1997], Boeri [1999]). Countries with different types of labor regulations are observed to have fairly similar gross job flows. The lack of a causal relationship between regulations and gross job flows at the aggregate level may be due to different elements. Stringent labor regulations may be associated with other regulatory and institutional factors that also affect job flows. For example, Bertola and Rogerson [1997] argue that the greater compression 
of wages in Europe than in the U.S. can compensate the differences in labor regulations and so explain the similarity of the turnover rates. A more fundamental problem is that cross-country analyses of job flows may be flawed by severe omitted variable problems and measurement errors, including differences in the distribution of activity across industries and size of firms, as well as different cut-off points in the enterprise surveys from which job flow data are obtained. To try to tackle these problems, a few papers have recently assessed the impact of changes in labor regulations on job flows in individual countries exploiting reform episodes that were targeted at specific groups in the labor market (exploiting "natural experiments") and generally found a significant negative effect of strict employment protection on job flows as well as substitution effects (see Kugler [2007]). ${ }^{1}$

In this paper, we draw from a harmonized and integrated firm-level dataset including 16 developed, emerging and transition economies of Eastern Europe. With these data, we explore in detail the industry and size dimensions of the job flows, and relate them to institutional differences across countries. Two recent papers exploit job flows across industries within countries to investigate the role of employment protection: Micco and Pages [2006] and Messina and Vallanti [2006]. Messina and Vallanti [2006] focus on cyclical and secular variation in job turnover. The paper that is closest to ours in terms of questions and approach is Micco and Pages [2006]. The latter paper exploits industry level gross job flows data for manufacturing for 18 countries and uses a difference-in-difference specification close to the specification we consider in this paper. Our analysis differs from this study along a number of related key dimensions. First, we use a harmonized firm-level database that covers all firms with at least one employee for both manufacturing and non-manufacturing sectors. Second, we exploit country, industry and firm size variation in our analysis. Interestingly, we find that firm size is by far the most important factor accounting for variation in the job flows across country, industry and firm size classes. This suggests that exploiting data by firm size is important both to provide greater within country variation in job flows for our empirical identification strategy but also that distortions to job flows across countries may very well interact with the flow and firm size relationship. Finally, our data allow distinguishing between job flows generated by the entry and exit of firms and those generated by the reallocation of labor by incumbent firms. As shown in the paper, this sheds additional light on labor reallocation and the role of regulations in labor and product markets.

\footnotetext{
${ }^{1}$ Kugler [2007] summarizes a number of empirical studies that have looked at the effects of reform episodes on job flows in Italy, France, Spain, Germany and the United States. These episodes provide "natural experiments" that allow comparing groups of workers targeted by the reform to groups of workers not directly affected by the reform before and after the policy change in what is otherwise the same macroeconomic and regulatory environment. The main conclusion of these studies is that increasing the strictness of employment protection legislation reduces job (and worker) flows, while the composition of employment is also swayed against young and female workers.
} 
To give a preview of our results, we find that countries share a number of features of job flows along the industry and size dimensions. All countries are characterized by large job flows. These vary significantly and systematically across industries, pointing to technological and market-driven factors, but they vary especially across firms of different sizes. To provide perspective on the importance of firm size, we find that industry effects alone account for about 5 percent of the variation in job reallocation rates across industry, size and country classes while firm size effects alone account for about 47 percent of the same variation. However, even after controlling for industry and size effects, there remain notable cross-country differences in job flows. In this paper, we develop a formal test of the role that hiring and firing regulations have in explaining these differences, and also test for the robustness of our results to the inclusion of other regulations affecting business operations. We use a difference-in-difference approach whereby we identify an industry and size class's baseline job reallocation from the United States data. The advantage, compared with standard cross-country/cross-industry empirical studies, is that we exploit within country differences between industry $\times$ sizes based on the interaction between country and industry $\times$ size characteristics. Thus, we can also control for country and industry $\times$ size effects, thereby minimizing the problems of omitted variable bias and other misspecifications. Interestingly, we find support for the general hypothesis that hiring and firing costs

reduce turnover, especially in those industries and size classes that require more frequent labor adjustment. Moreover, stringent labor regulations have more of an impact on job flows resulting from the entry and exit of firms than from reallocation among incumbents.

The remainder of the paper is organized as follows. Section 2 presents our harmonized firm-level dataset and discusses the different concepts we have used to characterize labor reallocation. Section 3 analyzes the main features of job flows, highlighting the role of firm dynamics, industry and size compositions. Section 4 introduces the difference-indifference approach used in the econometric analysis and discusses the empirical results for the baseline and policy augmented specifications of the job flow equations. It also describes a battery of robustness tests. Finally, section 5 presents concluding remarks.

\section{Data}

Our analysis of job flows draws from a harmonized firm-level database that includes 16 industrial, emerging and transition economies (Germany, Finland, France, Italy, Portugal, the United Kingdom and the United States, Estonia, Hungary, Latvia, Slovenia, Argentina, Brazil, Chile, Colombia and Mexico) and covers the 1990s (the time period covered varies 
by country - see Table A.1). ${ }^{2}$ The data collection was conducted by an active participation of local experts in each of the countries, and involved the harmonization of key concepts to the extent possible (such as entry and exit of firms, job creation and destruction, and the unit of measurement), as well as the definition of common methods to compute the indicators (see Bartelsman et al. [2007] for details). ${ }^{3}$

The key features of the micro-data underlying the analysis are as follows:

Unit of observation: Data used tend to conform to the following definition: "an organizational unit producing goods or services which benefits from a certain degree of autonomy in decision-making, especially for the allocation of its current resources" (EUROSTAT [1998]). Generally, this will be above the establishment level.

Size threshold: While some registers include even single-person businesses (firms without employees), others omit firms smaller than a certain size, usually in terms of the number of employees (businesses without employees), but sometimes in terms of other measures such as sales (as is the case in the data for France). Data used in this study exclude single-person businesses. However, because smaller firms tend to have more volatile firm dynamics, remaining differences in the threshold across different country datasets should be taken into account in the international comparison.

Industry coverage: Special efforts have been made to organize the data along a common industry classification (ISIC Rev.3) that matches the OECDStructural database (STAN). In the panel datasets constructed to generate the tabulations, firms were allocated to the single STAN industry that most closely fit their operations over the complete time-span.

The firm-level and job flows data come from business registers (Finland, the United Kingdom and the United States, Estonia, Latvia, Slovenia), social security databases (Germany, Italy, Mexico) or corporate tax rolls (Argentina, France, Hungary). Annual industry surveys are generally not the best source for firm demographics, due to sampling and reporting issues, but have been used nonetheless for Brazil, Chile, and Colombia. Data for Portugal are drawn from an employment-based register containing information on both

\footnotetext{
${ }^{2}$ The database also includes Indonesia, South Korea and Taiwan (China) as well as Canada, Denmark, the Netherlands, Romania and Venezuela, but annual data on job flows are not available for these countries or are not fully reliable.

${ }^{3}$ Micco and Pages [2006] compiled a dataset from different country sources covering 2-digit manufacturing sector information for 18 countries. Their dataset does not include transition countries, and does not allow differentiating job flows by firm status and firm size for all the countries.
} 
establishments and firms. All these databases allow firms and jobs to be tracked over time because addition or removal of firms from the registers reflects the actual entry and exit of firms.

We define four size classes based on the number of firm employees: 1- 19 workers, 20-49 workers, 50-99 workers, and 100 or more workers. The job reallocation rate (sum) is defined as the sum of job creation and job destruction rates, ${ }^{4}$ and we allow those to vary by the type of firm: entering, exiting or continuing firms. Job creation rate is defined as $\operatorname{pos}_{\text {sict }}=\frac{\sum_{i \in S C^{+}} \Delta E_{\text {sict }}}{0.5\left(E_{\text {sict }}+E_{s i c, t-1}\right)}$ and job destruction rate as neg $g_{\text {sict }}=\frac{\sum_{i \in S C^{-}} \Delta E_{\text {sict }}}{0.5\left(E_{\text {sict }}+E_{\text {sic }, t-1}\right)}$, where $i$ represents industry, $s$ represents size class, $c$ represents country, $t$ represents time and $E$ denotes employment. Capital letters $S$ and $C$ refer to a set of size classes or countries, respectively. The symbol $\Delta$ denotes the first-difference operator, $\Delta E_{t}=E_{t}-E_{t-1} \cdot{ }^{5}$

\section{Basic Facts about Job Turnover in Industrial and Emerging Economies of Latin America and Central and Eastern Europe}

This section reviews the main stylized facts emerging from our analysis of job flows across countries, industries and firm size. ${ }^{6}$ We review these stylized facts below to motivate our multivariate analysis. A slightly longer list of the basic facts as well as their more detailed description can be found in Haltiwanger et al. [2006].

\section{Large Job Turnover in All Countries}

The first stylized fact emerging from the data is the large magnitude of gross job flows (the sum of job creation and job destruction) in all countries, both at the level of total economy and in manufacturing (see Haltiwanger et al. [2006]). Gross job flows range from about 25 percent of total employment on average in the OECD countries, to about 30 percent in Latin America and the transition economies (see Table B.1 in the appendix). By contrast, net employment changes were very modest if not nil in the OECD and the Latin America samples, while the transition economies recorded a significant net job growth in the period covered by the data, after the substantial job losses of the early phases of the transition.

The high measured pace of reallocation in all countries may reflect many factors. Taken at face value, the patterns suggest a high degree of dynamism in virtually all

\footnotetext{
${ }^{4}$ We take averages of pos and neg, and then calculate sum.

${ }^{5}$ See also Davis et al. [1996].

${ }^{6}$ See Geroski [1995] for a summary of the main stylized facts characterizing firm demographics.
} 
economies. However, as discussed in the introduction, there may be many different countryspecific factors that influence the overall pace of job reallocation. Accordingly, identification of the impact of regulations requires exploiting more than simply cross-country variation.

\section{Firm Turnover Plays a Major Role in Total Job Flows}

The second stylized fact is the strong contribution of firm creation and destruction to job flows. Entering and exiting firms account for about 30-40 percent of total job flows (see Table B.1 in the appendix). In the transition countries, entry was even more important in the early years of transition to a market economy, while the exit of obsolete firms became more predominant in the second half of the 1990s, both for the total economy and in manufacturing, when market contestability strengthened. ${ }^{7}$

\section{Small Firms Contribute Disproportionately to Job Flows}

Small firms account disproportionately for job flows and firm turnover in all countries of our sample. Figure 1 presents job reallocation rates by firm size classes and countries. In general, job reallocation is highest in firms with less than 20 employees, and the lowest in firms with $100+$ employees. In the United States, job turnover declines monotonically with firm size, and the decline is particularly marked among large units (100+). Latin American countries follow similar patterns to those of the United States, while the European countries, with the exception of France, have a less marked drop of job reallocation among larger units. The transition countries, on the other hand, show a steeper slope in smaller size classes, especially in the early years of transition. Our data also suggest similar patterns for firm turnover by size class and country (results not presented here). It is this variation of job flows by size class as well as the variation across industries and countries that we exploit in our empirical analysis.

The analysis of size specific job reallocation rates should be complemented with a decomposition of the overall job reallocation into that due to firms of different sizes. We find small firms account for the largest share of firm turnover and also for a significant, albeit less dominant, share of total job flows. In terms of shares of job reallocation by size class, we find a U-shaped relationship that reflects two offsetting effects - first, job flows are higher for small firms as evidenced in Figure 1 and second, employment is concentrated in larger firms.

\section{Analysis of Variance}

The next step is to assess the relative importance of the different dimensions - country, industry and size - in explaining the overall variance in job flows. Table 1 presents the

\footnotetext{
${ }^{7}$ The large job flows in the transition countries are not surprising. The process of transition started in the early 1990s and it included downsizing or exit of existing firms as well as the entry of new firms as the economies progressed toward a market economy.
} 
Figure 1: Job Reallocation across Firms of Different Sizes, Total Economy
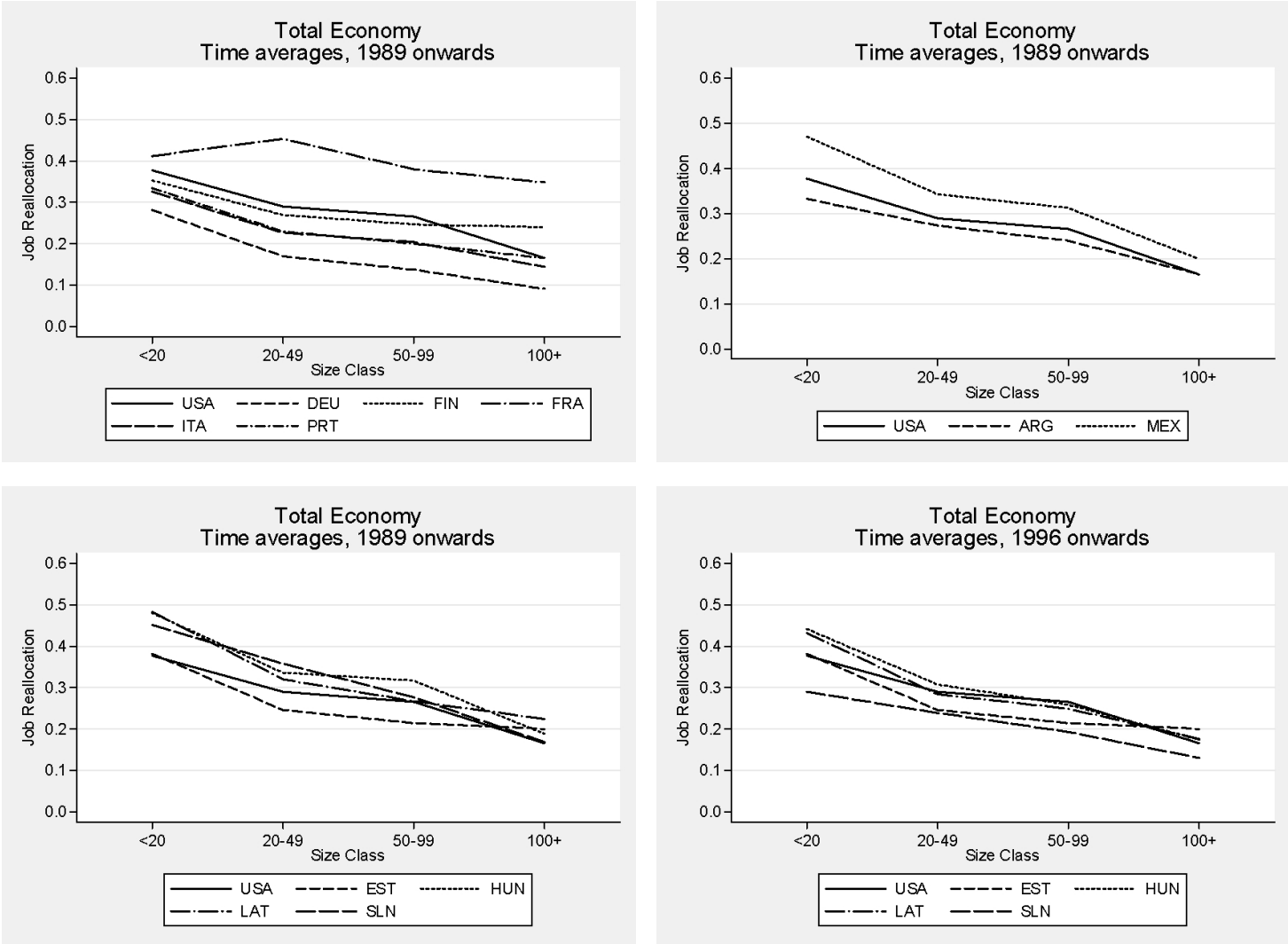

Source: Own calculations based on harmonized firm-level database.

analysis of variance of job flows, for the unbalanced total economy sample. ${ }^{8}$ We consider different indicators of job flows - gross job reallocation, excess job reallocation, job reallocation from entry and exit and job reallocation for continuers. We also assess the contribution to total variance of industry, size, country and industry $\times$ size effects separately, and, in addition, differentiate the analysis of variance by region (OECD, transition economies and Latin America).

It is noticeable that technological and market structure characteristics that are reflected in the industry-specific effects explain only 5.1 percent of the overall variation in gross job reallocation across industry, size and country classes, although they account for a higher share in Latin America (18.4 percent). By contrast, differences in the size structure of firms explain as much as 47 percent of the total variation in cross-country gross job reallocation in all regions. Even country effects explain more of the variation in gross job reallocation than the industry effects, except in Latin America. Hence, even though there

\footnotetext{
${ }^{8}$ The total economy sample is unbalanced in the sense that it covers manufacturing only for United Kingdom, Brazil, Chile and Colombia - see Table A.1 for details.
} 
are similarities among countries within a region, there is still significant variation across them. Overall, the combined industry $\times$ size effects explain the bulk of the variation in gross job reallocation: 52.2 percent overall, 46.7 percent in OECD countries, 64.3 percent in Latin American countries and 55.8 percent in transition countries in the second half of the 1990s.

Size heterogeneity plays a particularly strong role in explaining the variation of job creation by new firms and job destruction by exiting firms. Size heterogeneity is particularly important in Latin America, where it accounts for 80 percent of the heterogeneity in job reallocation from entry and exit. In the OECD countries, size heterogeneity plays a smaller role in both job reallocation from entering and exiting firms. ${ }^{9}$ It is also interesting that size and industry $\times$ size effects account for a substantially larger fraction of entry and exit variation than for continuers. Apparently, a key component that accounts for variation in job reallocation across industry $\times$ size and size classes is differences in the pace of entry and exit. Put differently, it suggests that the margin of adjustment that is used to accommodate higher job flows is entry and exit and, as such, our working hypothesis is that it may be this variation that is especially sensitive to distortions.

\section{The Correlation of Industry $\times$ Size Job Flows Across Countries}

It is also of importance to assess the correlation of industry job flows across countries. If market-driven and technological factors were the only factor at play, we should observe a strong correlation across countries. However, industry-level job flows in each country are also influenced by the institutional environment in which firms operate. Lack of correlation may not therefore imply that market-driven and technological factors do not play a significant role, but rather that policy and institutions distort job flows. Job flows are part-and-parcel of the creative destruction process, and an unfavorable institutional environment will cause this process to stagnate (Caballero and Hammour [2000a]). To minimize the possible interference of the policy environment, we present the rank correlation of industry job flows, which may provide a better proxy for the true correlation if the policy environment affects levels but not the rank order of industry $\times$ size flows.

Industry $\times$ size-level correlations with the U.S. are particularly strong for some Latin American countries, e.g. Brazil (0.90) and Colombia (0.92), despite the very different

\footnotetext{
${ }^{9}$ In unreported results, we have examined the analysis of variance separately for entry and exit. The most interesting aspect of this latter exercise is the finding that in the transition economies there is a strong difference between the factors accounting for variation in job creation and destruction. The variation of job creation by entrants is strongly influenced by size heterogeneity, while the importance of size effects for variation in job destruction by exiters is relatively small. The reason for the latter is that there are offsetting forces influencing exit in the transition economies. As in most countries, many young businesses fail in the early phases of their life, but in the transition economies (particularly in the early phases of their economic transformation) structural changes also involved the exit of many large, state owned enterprises.
} 
Table 1: Analysis of Variance, Total Economy (Unbalanced Panel)

\begin{tabular}{|c|c|c|c|c|}
\hline & $\begin{array}{r}\text { Gross Job } \\
\text { Reallocation }\end{array}$ & $\begin{array}{r}\text { Excess Job } \\
\text { Reallocation }\end{array}$ & $\begin{array}{r}\text { Job Reallocation } \\
\text { - Entry\&Exit }\end{array}$ & $\begin{array}{r}\text { Job Reallocation } \\
\text { - Continuers }\end{array}$ \\
\hline \multicolumn{5}{|c|}{ INDUSTRY EFFECTS } \\
\hline All & 0.0511 & 0.0373 & 0.0074 & 0.0924 \\
\hline OECD & 0.0730 & 0.0111 & -0.0386 & 0.1660 \\
\hline LAC & 0.1836 & 0.1120 & 0.0580 & 0.2585 \\
\hline Transition & -0.0274 & 0.0200 & -0.0386 & -0.0008 \\
\hline \multicolumn{5}{|c|}{ SIZE EFFECTS } \\
\hline All & 0.4690 & 0.4576 & 0.5008 & 0.1924 \\
\hline OECD & 0.4100 & 0.4430 & 0.4226 & 0.1750 \\
\hline $\mathrm{LAC}$ & 0.4724 & 0.5043 & 0.7023 & 0.1169 \\
\hline Transition & 0.5220 & 0.4894 & 0.4557 & 0.2966 \\
\hline \multicolumn{5}{|c|}{ COUNTRY EFFECTS } \\
\hline All & 0.1527 & 0.1311 & 0.1342 & 0.2172 \\
\hline OECD & 0.1910 & 0.1775 & 0.2115 & 0.2015 \\
\hline $\mathrm{LAC}$ & 0.1474 & 0.1158 & 0.0382 & 0.3640 \\
\hline Transition & 0.0758 & 0.0842 & 0.1020 & 0.1232 \\
\hline \multicolumn{5}{|c|}{ INDUSTRY $\times$ SIZE EFFECTS } \\
\hline All & 0.5215 & 0.4898 & 0.5069 & 0.2805 \\
\hline OECD & 0.4688 & 0.4251 & 0.3762 & 0.3157 \\
\hline LAC & 0.6430 & 0.5993 & 0.7958 & 0.2737 \\
\hline Transition & 0.5584 & 0.5319 & 0.4236 & 0.3328 \\
\hline
\end{tabular}

Source: Own calculations based on harmonized firm-level database.

degree of economic development, as well as for Great Britain (0.90) (Table 2). ${ }^{10}$ Some of the lowest correlations are found for some EU countries, in particular France (0.54). It is also interesting to see that transition economies had a much stronger correlation of their job flow patterns by industry and size class with the United States in the sample that covers the entire 1990s than in the sample used in this paper that focuses on the 1996-2001 period (see Haltiwanger et al. [2006]). This could be surprising, since the early phases of the transition were characterized by massive job reallocation and the unique need to change the structure of the economy. One working hypothesis that we develop later in the paper is that after the initial phases of transition, these countries have moved toward the job flow patterns observed in EU countries, with whom they share several policy and institutional factors.

\section{The U.S. vs. Other Countries in the "Slope" of the Industry $\times$ Size Re-}

\footnotetext{
${ }^{10}$ Correlations are on average higher if we focus only on manufacturing, see Haltiwanger et al. [2006] for more details.
} 
Table 2: Rank Correlations with the U.S. Job Flows, Total Economy (Unbalanced Panel)

\begin{tabular}{lrrrr}
\hline \hline & $\begin{array}{r}\text { Gross Job } \\
\text { Reallocation }\end{array}$ & $\begin{array}{r}\text { Excess Job } \\
\text { Reallocation }\end{array}$ & $\begin{array}{r}\text { Job Reallocation } \\
\text { - Entry\&Exit }\end{array}$ & $\begin{array}{r}\text { Job Reallocation } \\
\text { - Continuers }\end{array}$ \\
\hline OECD & $\mathbf{0 . 7 5 1 5}$ & $\mathbf{0 . 7 0 4 4}$ & $\mathbf{0 . 7 2 2 3}$ & $\mathbf{0 . 6 2 5 4}$ \\
\hline Germany & 0.8468 & 0.8634 & 0.9191 & 0.7214 \\
Finland & 0.6946 & 0.5837 & 0.3532 & 0.7742 \\
France & 0.5418 & 0.4670 & 0.7385 & 0.1762 \\
United Kingdom & 0.8994 & 0.8330 & 0.8229 & 0.6565 \\
Italy & 0.6901 & 0.6835 & 0.6896 & 0.6628 \\
Portugal & 0.8363 & 0.7957 & 0.8106 & 0.7611 \\
\hline LAC & $\mathbf{0 . 8 5 2 8}$ & $\mathbf{0 . 8 1 2 4}$ & $\mathbf{0 . 8 5 4 2}$ & $\mathbf{0 . 5 6 2 2}$ \\
\hline Argentina & 0.8844 & 0.8491 & 0.8421 & 0.7316 \\
Brazil & 0.8987 & 0.8526 & 0.9095 & 0.8135 \\
Chile & 0.6787 & 0.5444 & 0.7543 & -0.1212 \\
Colombia & 0.9170 & 0.9054 & 0.8975 & 0.6062 \\
Mexico & 0.8853 & 0.9104 & 0.8676 & 0.7807 \\
\hline TRANSITION & $\mathbf{0 . 7 5 5 6}$ & $\mathbf{0 . 7 5 4 6}$ & $\mathbf{0 . 6 9 0 5}$ & $\mathbf{0 . 5 9 0 3}$ \\
\hline Estonia & 0.7364 & 0.6932 & 0.6236 & 0.6338 \\
Hungary & 0.8321 & 0.8157 & 0.8560 & 0.6897 \\
Latvia & 0.7005 & 0.7392 & 0.7215 & 0.4204 \\
Slovenia & 0.7534 & 0.7702 & 0.5609 & 0.6171 \\
\hline Late 1990s data are used for transition countries. & & \\
\hline
\end{tabular}

Source: Own calculations based on harmonized firm-level database.

\section{allocation Relationship}

The findings from the previous two sub-sections suggest that industry $\times$ size effects account for a large fraction of the variation in job flows across industry, size and country classes, and also strong correlations between the rank order of job flows by industry and size in any given country with that in the United States. These findings help motivate our empirical analysis of regulations below since they clearly indicate that there are common factors underlining the patterns of job flows across countries and across industry and size classes. As discussed above, these patterns plausibly reflect technology, demand and cost fundamentals (including the distribution of idiosyncratic shocks and the costs of reallocation) that vary across industry and size classes. Before going to a more formal empirical analysis of the effects of policy-induced distortions on job flows, we run a simple descriptive regression in which we quantify how the "slope" of the industry $\times$ size relationship varies between the U.S. and the rest of the world. We take the U.S. as our benchmark because it is the country with arguably relatively low policy-induced distortions. In particular, we estimate the 
following regression:

$$
\text { JFlow }_{\text {sic }}=\beta_{0}+\beta_{1} \text { USJFlow }_{s i}+\sum_{c=1}^{C} \gamma_{c} D_{c}+\epsilon_{\text {sic }}
$$

where $D_{c}$ are country $c(c=1, \ldots, C)$ dummies, USJFlow si $_{\text {in }}$ is the U.S. job flow variable in size class $s$ and industry $i$, and $\epsilon$ is the iid error term. This specification enables us to quantify the relationship or slope between cross-industry $\times$ size differences in gross job flows between the United States and other countries in our sample. In this descriptive analysis, we start with a baseline specification in which we only include the U.S. job flow benchmark and the country dummies (equation (1)). We then allow the coefficient of the U.S. job flow variable to vary by region and by firm size class. ${ }^{11}$

As expected, the estimated coefficient on the U.S. job flow in column (1) in Table 3 is highly significant, confirming the bivariate correlation analysis discussed above. However, the estimated coefficient is significantly less than one, suggesting that, other things being equal, the responsiveness to market and technologically driven factors that affect reallocation in the U.S. is less than one in the other countries. Indeed, taking the U.S. job flow rate as the benchmark for the propensity for the industry $\times$ size class to exhibit reallocation from technology and market fundamentals, this finding suggests that when, for example, the propensity increases from one industry $\times$ size class to another in a fashion that induces a ten percent increase in job reallocation in the U.S., we observe only a 6.6 percentage point increase in job reallocation from the same industry $\times$ size class to the other in other countries in the sample. In a suggestive sense, the coefficient being less than one is consistent with the view that countries around the world have factors that distort the reallocation process. ${ }^{12}$

If we then allow the coefficient on U.S. job flows to vary by region (EU, transition countries and Latin America) (column (2)), we notice that there is a closer link between cross-industry $\times$ size differences in gross job flows between the United States and the Latin American countries than between the United States and the European Union countries. However, the coefficients are significantly less than one in all regions. Moreover, the coefficients on U.S. job flow for the European Union countries and for transition countries are not significantly different from each other at 1 per cent significance level (but they are dif-

\footnotetext{
${ }^{11}$ The measure of job flows is the sum of job creation and job destruction rates (sum) and all variables are time averages over the available annual observations (see the next section for more details).

${ }^{12}$ Appropriate caution needs to be used in interpreting the magnitude of the coefficient since measurement error can drive the coefficient below one. Still, we find it interesting that this coefficient is, in general, less than one, and that the pattern of variation in the magnitude of this coefficient across regions and size classes is consistent with our interpretation.
} 
Table 3: Job Flows - U.S. vs. Other Countries

\begin{tabular}{|c|c|c|c|}
\hline & $(1)$ & $\overline{(2)}$ & $\overline{(3)}$ \\
\hline USA SUM & $\begin{array}{r}0.6621^{* * *} \\
{[0.0188]}\end{array}$ & & \\
\hline USA $\mathrm{SUM} \times \mathrm{EU}$ & & $\begin{array}{r}0.5746^{* * *} \\
{[0.0284]}\end{array}$ & \\
\hline USA SUM $\times$ Transition & & $\begin{array}{r}0.6878^{* * *} \\
{[0.0352]}\end{array}$ & \\
\hline USA SUM $\times$ LAC & & $\begin{array}{r}0.7493^{* * *} \\
{[0.0340]}\end{array}$ & \\
\hline USA SUM $\times<20$ Workers & & & $\begin{array}{r}0.5385^{* * *} \\
{[0.0252]}\end{array}$ \\
\hline USA SUM ×20-49 Workers & & & $\begin{array}{r}0.3875^{* * *} \\
{[0.0350]}\end{array}$ \\
\hline USA SUM×50-99 Workers & & & $\begin{array}{r}0.3169^{* * * *} \\
{[0.0393]}\end{array}$ \\
\hline USA SUM $\times 100+$ Workers & & & $\begin{array}{r}0.2090^{* * * *} \\
{[0.0649]}\end{array}$ \\
\hline Country effects & YES & YES & YES \\
\hline Observations & 940 & 940 & 940 \\
\hline Adjusted R-squared & 0.69 & 0.69 & 0.73 \\
\hline \multicolumn{4}{|c|}{$\begin{array}{l}\text { All regressions include an intercept. Robust standard errors in brack- } \\
\text { ets. }{ }^{*}=\text { significant at } 10 \%,{ }^{* *}=\text { significant at } 5 \%,{ }^{* *}=\text { significant at } \\
1 \% \text {. USA SUM: industry } \times \text { size job reallocation in the United States. } \\
\text { EU denotes the OECD European countries. Transition denotes the } \\
\text { countries in Central and Eastern Europe. LAC denotes the countries } \\
\text { in Latin America. }\end{array}$} \\
\hline
\end{tabular}

Source: Own calculations based on harmonized firm-level database.

ferent at 5 per cent significance level). The Wald test for the equality of the coefficients on U.S. job flow for transition countries and for Latin American countries cannot be rejected at any of the usual significance levels.

Next, we allow the coefficient on U.S. job flows to vary by firm size (column (3)) and we find - perhaps not surprisingly - that the coefficient is the highest for the smallest size class (1-19 employees) and declines monotonically for the larger size classes. In other words, the patterns of cross industry job flows in the United States and other countries are more similar among small firms than among larger firms, possibly because small firms are exempt from certain regulations and/or can more easily avoid other regulations. Hence, small firms show a degree of dynamism that is closer to that of the non-distorted (U.S.) 
economy. For larger firms, regulations are likely to be more binding, especially in those industries that are inherently more volatile. The equality of all pairs of coefficients can be rejected at 1 per cent significance level; the highest values of Wald test are obtained in pairs with the coefficient for the smallest size class, indicating that the coefficient for the smallest size class is highly significantly different from those of larger size classes.

\section{Empirical Analysis}

\subsection{The Framework}

In this section, we develop an empirical analysis of the determinants of the observed differences in job flows across countries, industries and size classes. We base our empirical analysis on three important results discussed in the previous section: 1) a significant share of the total variance in job flows observed in the data is explained by industry $\times$ size effects, 2) there is a high correlation of industry $\times$ size job flows across countries, and 3 ) other countries tend to have less variation across industry $\times$ size classes in the magnitude of reallocation than the U.S. The first two results are consistent with the hypothesis that the distribution of idiosyncratic profit shocks affecting desired employment and the costs that influence the adjustment to such shocks varies systematically by industry and size class. For example, demand characteristics in some industries imply that firms face higher volatility in their product demand than other industries. Likewise, technological characteristics may require more frequent re-tooling of the production process with the associated need to adjust the workforce. Alternatively, certain technological characteristics may require firms to use highly specialized workers and thus make them less likely to frequently adjust their workforce to respond to idiosyncratic shocks. Demand and technological characteristics also affect the composition of firms within each industry and their response to shocks. For example, some industries are characterized by the presence of small firms which tend to be more volatile than large businesses in all countries. As discussed in the prior section, the third result is suggestive that there are factors that impede reallocation differences across industry $\times$ size classes in other countries relative to the U.S. Our empirical analysis in this section is designed to identify and quantify such factors. Before proceeding to that empirical analysis, it is instructive to review the insights from the recent literature on adjustment costs and reallocation (see, e.g., Caballero et al. [1997]).

Adjustment costs governing responses to idiosyncratic shocks vary not only by industry and size, due to underlying market and technological factors, but also across countries, due to differences in institutions and policy settings. To the extent that institutions vary 
Figure 2: Distribution of productivity shocks and fixed adjustment costs - two-sector case
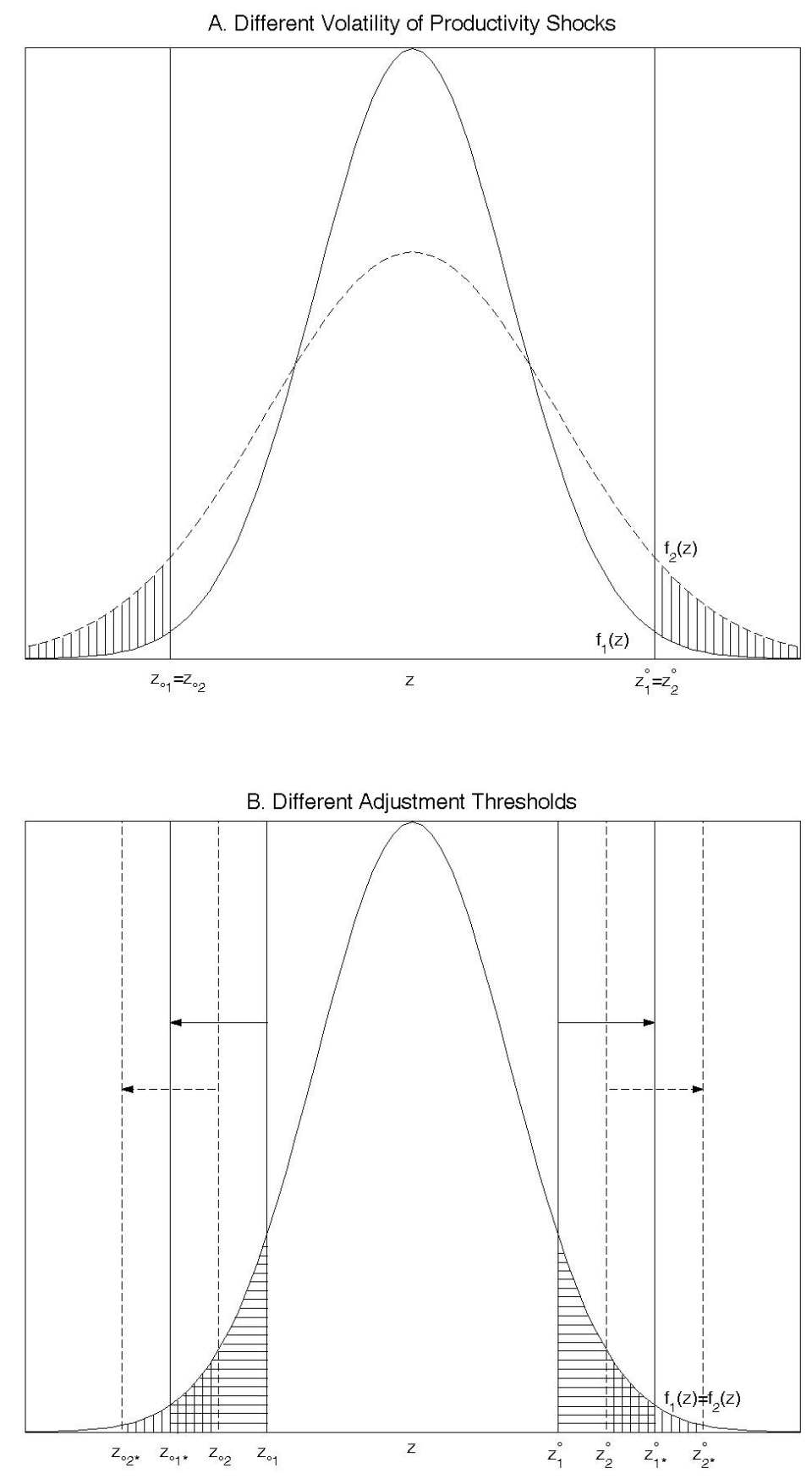

more by country than industry and size, our working hypothesis is that the impact of institutions that hinder adjustment in any given country will be more binding on industry $\times$ size 
cells with the greatest propensity for reallocation in that country. The amount of job reallocation in a particular sector hence depends on the distribution of productivity shocks $(z)$ and adjustment costs.

A simple $(S, s)$ model with fixed costs of adjustment can be used to illustrate the logic behind our argument. First, consider two sectors, 1 and 2, where sector 2 has a higher variance of productivity shocks and both sectors have the same thresholds of adjustment, $z_{\circ 1}=z_{\circ 2}$ and $z_{1}^{\circ}=z_{2}^{\circ}$, as illustrated in Panel A of Figure 2 where $f_{1}(z)$ and $f_{2}(z)$ represent the probability density function of productivity shocks. The sector with a higher variance of productivity shocks has a larger fraction of firms in the tails - the range of activity where the firms adjust to the new conditions - and in an associated manner more mass of the distribution at the adjustment thresholds. Hence, as our working hypothesis suggests, more volatile sectors are more sensitive to regulations or institutional factors that raise adjustment costs for firms, since they have a higher fraction of firms in the range of activity impacted by such adjustment costs.

Second, Panel B of Figure 2 considers the case of two sectors with the same variance of productivity shocks; however sector 2 has higher adjustment costs and hence a wider range of inactivity (which is illustrated by $z_{\circ 2}<z_{\circ 1}$ and $z_{2}^{\circ}>z_{1}^{\circ}$ ). If adjustment costs in a country increase for both sectors because of more stringent regulations - for example, stricter employment protection legislation - the thresholds will be pushed to $z_{\circ 1 *}<z_{\circ 1}$, $z_{1 *}^{\circ}<z_{1}^{\circ}, z_{\circ 2 *}<z_{\circ 2}$ and $z_{1 *}^{\circ}<z_{1}^{\circ}$. Sectors with originally lower adjustment costs will be more adversely affected, since increase in adjustment costs will push a higher fraction of firms from the range of adjustment (reallocation) to the range of inactivity (no reallocation).

This simple $(S, s)$ model illustrates the basic argument for incumbent firms, but it is straightforward to extend its argument to include the entry and exit of firms. Indeed, standard models of entry and exit (e.g., Jovanovic [1982], Hopenhayn and Rogerson [1993], Melitz [2003], Asplund and Nocke [2006]) posit that new entrant firms do not know, ex ante, their productivity type and must pay an entry fee before learning their type. Firms enter the market until the expected present discounted value of profits from entry is just equal to the entry cost. Firms with low productivity draws exit ex post. Higher adjustment costs - including labor adjustment costs - reduce the present discounted value of ex ante profits, especially for sectors with a high variance of productivity shocks (for the reasons discussed above). This yields a lower pace of entry as well as an implied lower pace of exit in the steady state. The model that illustrates this effect most directly is Hopenhayn and Rogerson [1993] who show that higher employment adjustment costs lead to a lower pace of job and firm turnover. 


\subsection{The Estimation Model}

We explore the links between the regulatory environment in which firms operate and job turnover by exploiting the observed industry $\times$ size variations through a difference-indifference approach (see Rajan and Zingales [1998]). ${ }^{13}$ The test is constructed as follows: we identify an industry $\times$ size propensity for job reallocation from the United States data. Under the assumption that regulations in the labor and goods markets in the United States are among the least restrictive in our sample, variation in job reallocation across industry $\times$ size cells in the United States should proxy for the technological and market driven differences in job reallocation in the absence of policy induced adjustment costs. Under the additional assumption that these technological and market driven differences in the demand for job reallocation carry over to other countries, we assess whether industry $\times$ size cells that have a greater propensity for job reallocation are disproportionally affected by regulations that raise adjustment costs. This would imply that, ceteris paribus, industry $\times$ size cells with more volatile idiosyncratic profit shocks and more frequent adjustment of factors should be more strongly affected by regulations raising adjustment costs than those industry $\times$ size cells with less volatile idiosyncratic profit shocks and less frequent adjustment. The advantage of our approach compared to standard cross-country/cross-industry empirical studies is that we exploit within country differences between industry $\times$ size cells based on the interaction between country and industry $\times$ size characteristics. Thus, we can also control for country and industry $\times$ size effects, thereby minimizing problems of omitted variable bias and other misspecifications.

The core model specifications used in our empirical analysis can be summarized as follows:

$$
\text { JFlow }_{\text {sic }}=\beta_{0}+\sum_{s i=1}^{S \times I} \gamma_{s i} D_{s i}+\sum_{c=1}^{C} \gamma_{c} D_{c}+\beta_{2}\left(\text { USJFlow }_{s i} \times R_{c}\right)+\epsilon_{\text {sic }}
$$

where $D_{s i}$ are industry $\times$ size $s i(s i=1, \ldots, I \times S)$ dummies, $D_{c}$ are country $c(c=1, \ldots, C)$ dummies, USJFlow Us $_{\text {is }}$ the U.S. job flow variable in size class $s$ and industry $i$, and $\epsilon$ is the iid error term. Controlling for country effects sweeps out any country-specific variation, controlling for industry $\times$ size effects sweeps out the large common factors associated with industry and size, and the key interaction term between the U.S. flow in the industry $\times$ size class and the country regulation allows us to identify how the measured regulatory environment affects the variation across industry $\times$ size classes within countries. The U.S.

\footnotetext{
${ }^{13}$ The difference-in-difference approach has already been used in the corporate literature (e.g., Classens and Laeven [2003]), in the analysis of firm dynamics (Klapper et al. [2006]) and in the analysis of output and employment growth as well as job flows (Micco and Pages [2006]).
} 
flow here is used to quantify the propensity for the industry $\times$ size class to reallocate and, as discussed, reflects the fundamental driving forces underlying job reallocation across industry $\times$ size classes.

In what follows, the measure of job flows used in the empirical analysis is the sum of job creation and job destruction rates (sum). The results are largely unaffected by the use of excess job reallocation, that is, the difference between the sum and the (absolute value of) net employment change. All our variables are time averages over the available annual observations. The sample is unbalanced and covers fewer years for some countries than others (see Table A.1). Time averaging allows us to reduce the possible impact of business cycle fluctuations in the years for which we have the data and the possibility that such fluctuations were not synchronized (and thus could be captured by common time dummies). We use the period from 1989 to 2001 for OECD and Latin American countries and sample from 1996 to 2001 for the transition economies. The choice of the restricted sub-sample for the transition economies is motivated by two interrelated factors. First and as discussed in the previous section, the initial years of the transition process (1991 to 1995) were characterized by unprecedented reallocation of labor - and other factors of production - across industries, firms and locations. The magnitude and direction of the observed flows were only temporary and, indeed, job flows declined towards the standards of the OECD countries over time, and also became more balanced within each industry $\times$ size cell. ${ }^{14}$ Second, the early years of transition were characterized by major regulatory reforms to conform countries' institutional settings to those of market economies. For these two reasons, focusing on the second half of the 1990s for the transition economies is more appropriate in our comparative analysis of job flows. ${ }^{15}$

In addition to the core specification, we consider some closely related specifications. As a robustness check, we estimate an augmented model that also considers business sector regulations. In addition, we explore specifications that focus on, alternatively, job flows from entry and exit or continuing firms.

\subsection{Regulations in Labor and Product Markets}

In the empirical analysis, we consider synthetic indicators of the stringency of regulations in the labor and product markets, as well as the degree of enforcement of laws and regulations. Our primary source for these is the "Economic Freedom of the World (EFW)" database (see Gwartney and Lawson [2004]). This database has been developed under the auspices

\footnotetext{
${ }^{14}$ Results for the whole sample for transition economies are available in Haltiwanger et al. [2006].

${ }^{15}$ Dataset used in the paper is available at http://www.helenasch.net.
} 
of the Fraser Institute in Canada with the aid of a worldwide network of economists and research institutes. In particular, we use indicators referring to hiring and firing practices, regulation of business activities and integrity of the legal system.

Other indicators of the stringency of labor regulations in developing and emerging economies are available in the literature (e.g., the World Bank Doing Business database), but they generally refer to the most recent past and may thus not properly capture the regulatory environment over the period covered by our data (the 1990s). By contrast, the EFW tracks changes in regulations over time and is thus more suitable for our analysis of job flows that have indeed been influenced by policy changes over the period covered by our data (see Table C.1 for more detailed definitions of the variables used in our analysis and Table C.2 for their summary statistics).

The EFW indicator of hiring and firing restrictions is measured on a scale of 0 to 10 , with 10 being the worst (most restrictive). The average of this indicator is the highest in transition countries (5.70), followed by the OECD sample (5.43) and Latin America (4.68). This synthetic indicator passes simple validation tests. For example, its correlation with a similar indicator of employment protection legislation developed by the OECD is 0.85 , statistically significant at the 1 percent level. ${ }^{16}$

In the sensitivity analysis, we also consider an EFW synthetic indicator of regulations in the product market. Regulations affecting markets for goods and services have a strong impact on the degree of competition and the pace and effectiveness of reallocation of resources, including labor. Thus, more restrictive regulations that stifle product market competition are also likely to influence job flows. The business regulation indicator is a simple average of five different indicators ${ }^{17}$ that are designed to identify the extent to which regulatory restraints and bureaucratic procedures limit competition and the operation of goods and services markets. Business regulation is measured on a scale from 0 to 10 , with 10 being the most restrictive. This indicator is on average the highest in Latin America (4.21), followed by transition countries (3.32) and OECD countries (3.07).

\footnotetext{
${ }^{16}$ We check the robustness of our results by using an alternative measure of employment protection legislation, the OECD EPL index. Since this measure is not available for Latin America and transition countries in the early 1990s, we augmented it in two ways. First, for transition countries we used data on EPL collected by Haltiwanger et al. [2003]. Second, for Latin America we imputed EPL by regressing a measure of hiring and firing practices from the Fraser Institute on EPL for transition and OECD countries and then using the estimated coefficient to calculate EPL. EPL is measured on a scale from 0 to 4 , with 4 being the worst (most restrictive). It is on average the strictest in OECD (2.35) and the least strict in Latin America (1.73).

${ }^{17}$ The detailed indicators used to construct the synthetic indicator are: price controls, administrative conditions and new business, time with government bureaucracy, starting a new business, and irregular payments.
} 
Previous research (see, e.g., Caballero et al. [2004], Heckman and Pages [2004]) suggests that the degree of enforcement of labor regulations - as well as other regulations - can significantly affect their impact on the economy. Available indicators suggest a significant variation in the rules of law and the degree of enforcement of laws and regulations in our sample of OECD, Latin American and transition economies. Not only are some firms and jobs not registered in Latin America and increasingly in the transition economies and some Southern European countries, registered firms may also not fully comply with the existing rules and regulations. As an indication of the different degree of enforcement of laws and regulations, we consider the law and order indicator from the Fraser Institute (based on the Political Risk Component I (Law and Order) from the International Country Risk Guide, ranging from 0 to 10,10 being the worst). ${ }^{18}$ The indicator shows the highest compliance with laws and regulations in the OECD sample of countries (average of 0.47), followed with the transition economies (average of 1.76), and by the Latin American countries (average of 4.95).

To control for possibly differing degrees of enforcement of laws and regulations we adjust our regulatory variable as follows: ${ }^{19}$

$$
R_{c, a d j}=\left(1-\frac{\text { Law\&Order }}{10}\right) \times R_{c}
$$

\subsection{Regulations and Job Flows}

Tables 4 and 5 present the empirical results of the estimation of our core specification (2) and various extensions. Recall that in (2) we specify a difference-in-difference analysis that identifies the impact of regulations via the interaction effect of U.S. job flows in the industry $\times$ size class with the country-specific regulation. The estimated coefficient on the interaction between the U.S. job flow and the adjusted labor regulation (Table 4) is strongly significant overall, and in each of the sub-regions when we allow the coefficient of the interaction to vary. Consistent with the working hypothesis, more volatile industries and size classes are impacted more in countries with more stringent hiring and firing regulations. ${ }^{20}$

\footnotetext{
${ }^{18}$ Micco and Pages [2006] also make an attempt at controlling for different degrees of enforcement of regulations by using an indicator of rules of laws and government effectiveness (see Kaufmann et al. [2004]). We used the Fraser index of law and order because it is available for the time period for which our job flows data are available for the different countries.

${ }^{19}$ There is no indication in Gwartney and Lawson [2004] that the original regulatory variables consider the enforcement of regulations in addition to the statutes.

${ }^{20}$ In our longer working paper version (see Haltiwanger et al. [2006]), we have also considered a related specification where instead of controlling for industy $\times$ size effects we have included the U.S. industry $\times$ size flow separately to control for industry $\times$ size effects. In this alternative specification, we also include country
} 
Table 4: Job Flows and the Role of Labor Regulations (Difference-in-Difference Analysis)

\begin{tabular}{lrr}
\hline \hline & \multicolumn{1}{c}{$(1)$} & \multicolumn{1}{c}{$(2)$} \\
\hline USA SUM $\times$ EPL $($ Adj $)$ & $-0.0450^{* * *}$ & \\
& {$[0.0082]$} & \\
USA SUM $\times$ EPL $($ Adj $) \times$ EU & & $-0.0478^{* * *}$ \\
& & {$[0.0080]$} \\
USA SUM $\times$ EPL $($ Adj $) \times$ Transition & & $-0.0370^{* * *}$ \\
& & {$[0.0103]$} \\
USA SUM $\times$ EPL $($ Adj $) \times$ LAC & & $-0.0449^{* * *}$ \\
& & {$[0.0128]$} \\
\hline Country effects & YES & YES \\
Industry $\times$ size effects & YES & YES \\
\hline Observations & 940 & 940 \\
Adjusted R-squared & 0.77 & 0.77 \\
\hline All & &
\end{tabular}

All regressions include an intercept. Robust standard errors in brackets. ${ }^{*}=$ significant at $10 \%,{ }^{* *}=$ significant at $5 \%,{ }^{* * *}=$ significant at $1 \%$. USA SUM: industry $\times$ size job reallocation in the United States. EU denotes the OECD European countries. Transition denotes the countries in Central and Eastern Europe. LAC denotes the countries in Latin America. EPL (Adj) is an indicator of stringency of hiring and firing regulations adjusted to take into account different degrees of enforcement of regulations (see main text).

Source: Own calculations based on harmonized firm-level database.

How sizable is the estimated impact of labor regulation on job flows? Using the coefficient on the interaction term in column (1) of Table 4, we estimate that the difference in job reallocation between industry $\times$ size cells with a high flexibility requirement $\left(90^{\text {th }}\right.$ percentile of the flexibility distribution in the United States) and industry $\times$ size cells with a low flexibility requirement ( $10^{\text {th }}$ percentile of the same distribution) will be 4.4 percentage points lower in a country with the highest index of hiring and firing regulations compared to the United States, the country with the least restrictive regulations. Considering that the average job reallocation rate is around 25 percent in the sample used in the regression,

effects. This alternative specification is more parsimonious since far fewer degrees of freedom are used to control for industry $\times$ size effects. Interestingly, we find virtually identical results for this alternative specification and for purposes of brevity do not report those results here. It is also interesting that the estimated coefficient of the U.S. job flow benchmark is closer to unity than when we do not control for enforcement (see Table 3). This finding suggests that part of the less than perfect correlation in the magnitude of job flows in the countries in the sample with the United States can be explained by restrictive labor regulations that raise labor adjustment costs. 
Table 5: Job Flows and the Role of Labor and Product Market Regulations (Differencein-Difference Analysis)

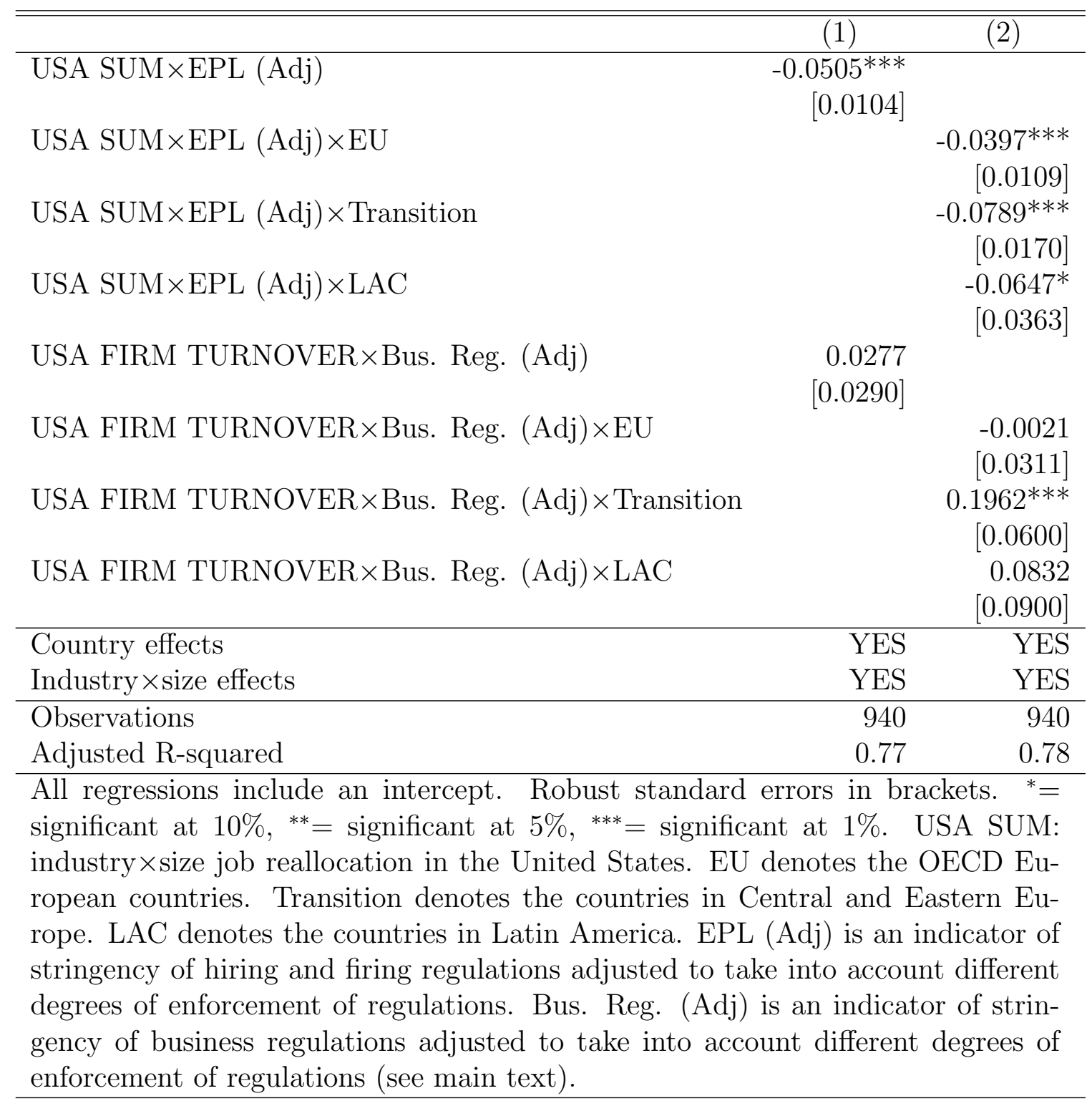

Source: Own calculations based on harmonized firm-level database.

the estimated impact is indeed sizeable. ${ }^{21}$

${ }^{21}$ The estimated value is obtained as follows:

$$
\beta\left[\left(U S J \text { Flow }_{90^{t h}}-U S J \text { Flow }_{10^{t h}}\right)\left(H F_{\max }-H F_{\min }\right)\right]
$$

where $\beta$ is the estimated coefficient, and USJFlow and $H F$ are the job reallocation in the United States and the indicator of hiring and firing regulations corrected for the degree of enforcement, respectively. Micco and Pages [2006], using a similar approach, estimated an impact of 5.7 percentage points. Their 
There are a number of reasons why it is important to assess the robustness of our results on labor regulations to the inclusion of regulations in product markets. First, the exclusion of product market regulations may lead to an omitted variable bias insofar as regulations in different markets tend to be highly correlated, i.e. countries that impose strict rules of hiring and firing also tend to impose more restrictive regulations on the goods and services markets. ${ }^{22}$ There are also specific aspects of product market regulations that can influence job flows over and above labor regulations. For example, since a significant fraction of overall job flows is due to the entry and exit of firms, regulations affecting the start up of a new business, as well as bankruptcy rules that affect the exit of low performing units, may affect job flows directly and the way incumbents react to strict labor regulations. Koeniger and Prat [2007], for example, argue that product and labor market regulations are complementary: by isolating incumbents from the competition of potential entrants, barriers to entry allow incumbents to bear the firing costs more easily. Likewise, regulations affecting price setting by firms and their relations with the public administration and their clients can all influence incentives for firms to expand, adopt new technologies and adjust their workforce.

To assess the robustness of our empirical results we thus augment our job flows specification by adding a synthetic indicator of the stringency of business sector regulations. As for labor regulations, we adjust this variable for the degree of enforcement (Table 5) and interact it with the US employment-weighted firm turnover. We use firm turnover rather than job flows here in the interaction term since business regulations primarily impact the entry and exit of firms. Thus, the more relevant propensity for reallocation is the reallocation component from firm turnover. ${ }^{23}$ The estimated effects of labor regulations on job flows remain strongly significant overall and in the different regions. By contrast, the estimated coefficient of business regulations is estimated with a large standard error overall. When we differentiate the coefficient by region, we find that the estimated effect of business regulations is positive and significant for transition economies. As we have discussed above, the transition economies exhibited unusual patterns of entry and exit by size class over at least some of the 1990s as large state owned firms exited which may be relevant for this pattern. ${ }^{24}$

country sample and period of observation are different from ours but the results are close.

${ }^{22}$ There is also ample evidence that regulations in product and labor market tend to be correlated across countries (see e.g. Nicoletti and Scarpetta [2005]).

${ }^{23}$ We have also used US job flows rather than firm turnover as the industry $\times$ size interacting factor: the results are largely similar to those reported in the paper and are available on request. We find some sensitivity in the specifications that also interact with region but the robustness of the labor regulations holds in this alternative.

${ }^{24}$ Indeed there are models that yield a positive relationship between business regulations impacting entry and exit and job turnover. For example, Koeniger and Prat [2007] have a model with both intensive and extensive (i.e. through firm entry and exit) margins of adjustment, and fixed and/or start-up costs imposed 
So far we have focused on the effects of labor regulations on overall job reallocation. It is also interesting to shed light on whether such regulations have a different impact on the different margins of reallocation, namely on job flows due to the entry and exit of firms in the market and those due to reallocation among incumbents (see Table 6). ${ }^{25}$

Table 6: Job Flows by Entering, Exiting and Continuing Firms - the Role of Labor Market Regulations (Difference-in-Difference Analysis)

\begin{tabular}{|c|c|c|}
\hline & $\begin{array}{c}\text { Entry \& Exit } \\
(1)\end{array}$ & $\begin{array}{c}\text { Continuers } \\
(2)\end{array}$ \\
\hline USA SUM (Entry\&Exit)×EPL (Adj) & $\begin{array}{r}-0.1073^{* * *} \\
{[0.0102]}\end{array}$ & \\
\hline USA SUM (Continuers) $\times$ EPL $($ Adj) & & $\begin{array}{r}0.0154 \\
{[0.0137]}\end{array}$ \\
\hline Country effects & YES & YES \\
\hline Industry $\times$ size effects & YES & YES \\
\hline Observations & 946 & 934 \\
\hline Adjusted R-squared & 0.78 & 0.62 \\
\hline $\begin{array}{l}\text { All regressions include an intercept. } \\
\text { ets. }{ }^{*}=\text { significant at } 10 \%,{ }^{* *}=\text { signific } \\
\text { USA SUM (Entry\&Exit): industry } \times \mathrm{s} \\
\text { ing and exiting firms in the United } \\
\text { industry } \times \text { size job reallocation due to } \\
\text { States. EPL (Adj) is an indicator of st } \\
\text { lations adjusted to take into account }\end{array}$ & $\begin{array}{l}\text { obust standar } \\
\text { t at } 5 \%,{ }^{* * *}= \\
\text { e job reallocat } \\
\text { ates. USA St } \\
\text { continuing firr } \\
\text { ngency of hirin } \\
\text { ferent degrees }\end{array}$ & $\begin{array}{l}\text { ors in brack- } \\
\text { ificant at } 1 \% \text {. } \\
\text { due to enter- } \\
\text { (Continuers): } \\
\mathrm{n} \text { the United } \\
\text { d firing regu- } \\
\text { nforcement of }\end{array}$ \\
\hline
\end{tabular}

Source: Own calculations based on harmonized firm-level database.

Column (1) of Table 6 shows the results of estimating the job flow regressions for entering and exiting firms, controlling for labor market regulations corrected by the degree of enforcement. Column (2) does the same for continuing firms. The results suggest a negative and statistically significant effect of labor market regulation (interacted with U.S. job reallocation) on labor mobility generated by entering and exiting firms. By contrast, the effect of labor regulations on continuing firms is not statistically significant. ${ }^{26}$

by product market regulations. They find that product market regulations lead to higher job turnover, as the competition for workers is alleviated by the firm selection effect, the costs of adjusting the labor force decrease and thus firms have less incentive to smooth out their labor demand schedule.

${ }^{25} \mathrm{We}$ focus on the combined flows due to entry and exit of firms because of the very high correlations between entry and exit across industries in most countries. This in turn suggests that entries and exits are largely part of a creative destruction process in which entry and exit reflect within industry reallocation reflecting idiosyncratic differences across firms within industries (see Bartelsman et al. [2004] for evidence based on the same dataset used in this paper, as well as Geroski [1991], Baldwin and Gorecki [1991]).

${ }^{26}$ In Table 6, we use the U.S. job reallocation for entry and exit as the propensity for entering and exiting 
That it is the entry and exit component of job turnover rather than the continuer component of job turnover that is impacted by labor market regulations is an interesting result that is somewhat surprising from a theoretical perspective but perhaps not surprising given the findings from our analysis of variance. From a theoretical perspective, the implications from standard adjustment cost models discussed above suggest we should observe an impact for continuers and entry and exit. Taken at face value, the results provide support for the theory in terms of the entry and exit component but not for the continuer component of job turnover. It may be that a richer model needs to be developed to account for this finding - one interesting idea suggested by this result is that labor regulations distort the entry and exit margin to such an extent that job turnover patterns for continuers are not impacted. That is, overall job turnover is stifled via labor market regulations but with a substitution towards adjustment of continuing firms relative to adjustment via entry and exit.

While exploring the implications of this result are of interest both theoretically and empirically, we note however that the analysis of variance as reported in Table 1 provides insights on interpreting this empirical result. The analysis of variance results show that variation in job flows across industry $\times$ size effects is dominated by variation in the entry and exit component of job turnover. Thus, an important part of the variation that we are exploiting for identification and, in like fashion an important component of the variation that can be distorted by regulations, is the variation across industry $\times$ size classes in entry and exit rates. This interpretation suggests that the variation we are exploiting is best suited for identifying an effect coming from entry/exit since that is where the variation is most pronounced. To identify the impact on continuing businesses using this type of differencein-difference approach, it may be important to find another dimension of variation across firms with sufficient variation across continuing firms.

Overall, these results confirm the importance of labor market regulations in shaping labor adjustment patterns, particularly so in those industries and size classes where technological and market factors require more frequent employment changes. Controlling for other regulations influencing firm behavior does not significantly alter the results. There is also evidence in our data that labor market regulations are important mainly for entering and exiting firms.

firms and the U.S. job reallocation for continuers as the propensity for reallocation for continuers. We have also considered alternative specifications where for both propensities we use the overall job reallocation for the industry $\times$ size class and obtain very similar results. We also estimate the job flow regressions for entering and exiting firms separately and find that labor market regulations affect both entry and exit margins. 


\subsection{Sensitivity Analysis}

In the empirical analysis, we control for country and industry $\times$ size effects, as well as for unobservable effects using a difference-in-difference approach. Moreover, we test the robustness of results for hiring and firing regulations by including other regulatory variables. In addition, we test the sensitivity of our results by using excess job reallocation instead of gross job reallocation, restricting our analysis to industry $\times$ size cells with more than five firms in a given cell and to manufacturing industries only (not reported here but available upon request). However, the use of quasi panel data may still run the risk that results are affected by the inclusion of a specific country or industry in the sample that drives the results in a given direction. The use of an unbalanced panel on the industry dimension makes this risk potentially more serious.

Figure 3: Sensitivity Analysis: Estimated Coefficient on Enforcement Adjusted Hiring and Firing Regulations Interacted with U.S. Job Reallocation and 95\% Confidence Intervals, Excluding One Country or One Industry at a Time, Labor Market Regulations (Column (1) from Table 4)
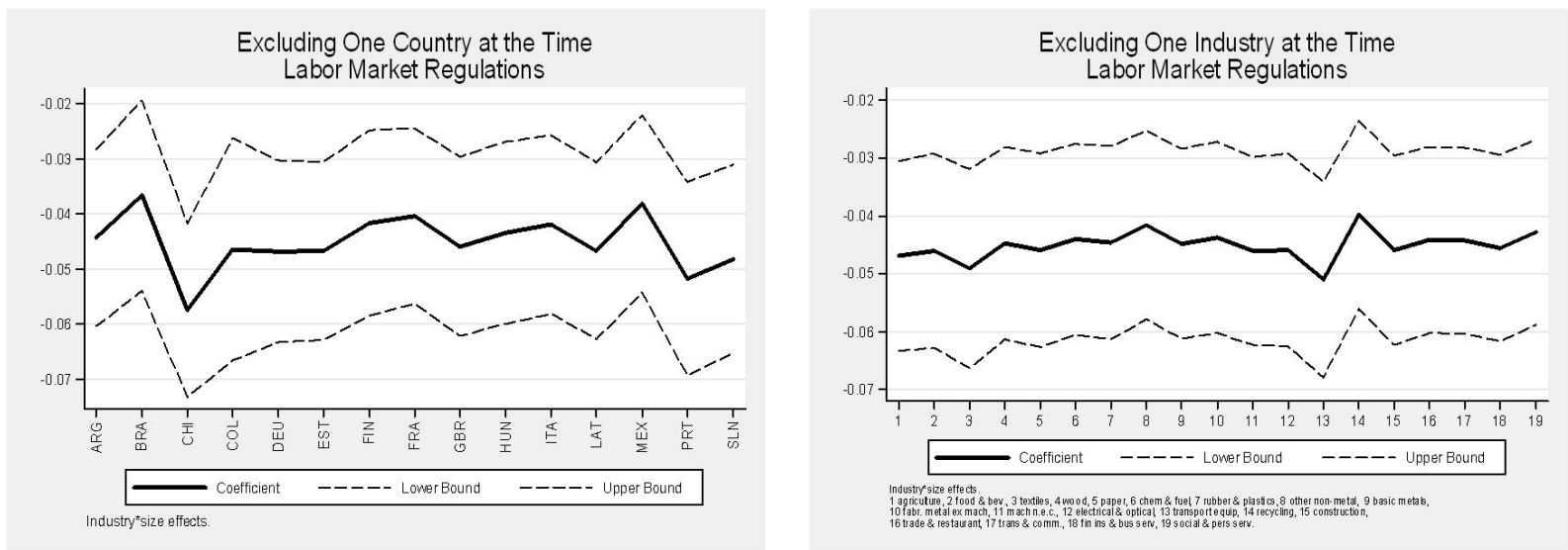

Source: Own calculations based on harmonized firm-level database.

To test for the robustness of results to changes in the sample, we re-estimate our preferred specification - column (1) in Table 4 - removing one country, or one industry, at a time from the sample. The results in Figure 3 show a remarkable stability of the estimated coefficient for the interaction term to changes in the sample along the country or the industry dimension. The point coefficient estimates for the interaction term are always negative and statistically significant. The coefficient is somewhat sensitive to the exclusion of Chile or Portugal, with both leading to a stronger estimated effect of regulations. 


\section{Conclusion}

This paper exploits a rich new database with harmonized data on job flows across industries and size classes for 16 industrial and emerging economies over the past decade. We find that all countries in our sample exhibit sizeable annual gross job flows. Industry and size-class effects together account for a very large share of the overall variability in job flows across country, industry and size class cells (e.g., over 50 percent of the variation in the summary measure of job reallocation is accounted for by industry and size effects interacted together). Interestingly, the most important factor here is employer size. Small businesses exhibit a substantially higher pace of job creation and destruction and this pattern is pervasive across industries and countries. Industry effects also play a significant, albeit much smaller, role in shaping job flows. Taken together, it is clear that some form of technology, cost and demand factors that are common across countries account for the bulk of the variation in job flows. Nevertheless, even after controlling for industry/technology and size factors, there remain significant differences in job flows across countries that could reflect differences in business environment conditions.

Our harmonized firm-level dataset allows us to look at two factors shaping the business environment - regulations on the hiring and firing of workers and product market regulations. To minimize the possible endogeneity and omitted variable problems associated with cross-country regressions, we use a difference-in-difference approach. The empirical results suggest that stringent hiring and firing regulations (and their consistent enforcement) reduce job turnover, especially in industry and size-class cells that inherently exhibit more job turnover. To capture the latter, we use the United States patterns as a benchmark to identify and quantify industry $\times$ size class cells with inherently higher job turnover. Labor regulations also appear to distort the patterns of flows across industry and size classes within a country. Stringent labor regulations mainly affect the entry and exit of firms and their associated job creation and destruction. Controlling for product market regulations does not alter these results significantly.

Much work remains to be done to understand the implications of our findings. They provide evidence that stringent labor regulations have an impact on reallocation dynamics. It is a much larger step to demonstrate that stringent labor regulations have an adverse impact on the efficient allocation of labor in a manner consistent with the predictions of Hopenhayn and Rogerson [1993]. To explore the latter, we need to measure not only reallocation but also productivity at the micro level. A number of studies have found that allocative efficiency is important for understanding differences in the level and growth

of productivity across time, industries and countries (see, e.g., Foster et al. [2001] and Bartelsman et al. [2007]). Putting those findings together with those in this paper certainly 
suggests that stringent labor market regulations may have an important adverse impact on allocative efficiency and in turn productivity levels and growth. However, much work

(including additional data infrastructure development) is needed to bring all of the pieces together to explore these important issues.

\section{References}

Marcus Asplund and Volker Nocke. Firm Turnover in Imperfectly Competitive Markets. Review of Economic Studies, 73(2):295-327, 2006.

John R. Baldwin and P. K. Gorecki. Entry, Exit and Productivity Growth. In Paul A. Geroski and Joachim Schwalbach, editors, Entry and Market Contestability: An International Comparison, pages 244-256. Blackwell, Oxford, 1991.

Eric J. Bartelsman, John C. Haltiwanger, and Stefano Scarpetta. Microeconomic Evidence of Creative Destruction in Industrial and Developing Countries. Working Paper 3464, World Bank, December 2004.

Eric J. Bartelsman, John C. Haltiwanger, and Stefano Scarpetta. Measuring and Analyzing Cross-Country Differences in Firm Dynamics. In Timothy Dunne, J. Bradford Jensen, and Mark J. Roberts, editors, Producer Dynamics: New Evidence from Micro Data. NBER, 2007.

Samuel Bentolila and Giuseppe Bertola. Firing Costs and Labor Demand: How Bad is Eurosclerosis? Review of Economic Studies, 57(3):381-402, July 1990.

Giuseppe Bertola. Labor Turnover Costs and Average Labor Demand. Journal of Labor Economics, 10(4):389-411, 1992.

Giuseppe Bertola and Richard Rogerson. Institutions and Labor Reallocations. European Economic Review, 41(6):1147-1171, June 1997.

Tito Boeri. Enforcement of Employment Security Regulations, On-the-job Search and Unemployment Duration. European Economic Review, 43(1):65-89, January 1999.

Ricardo J. Caballero and Mohamad L. Hammour. Institutions, Restructuring, and Macroeconomic Performance. Working Paper 7720, NBER, May 2000a.

Ricardo J. Caballero and Mohamad L. Hammour. Creative Destruction and Development: Institutions, Crises, and Restructuring. Working Paper 7849, NBER, 2000b. 
Ricardo J. Caballero, Eduardo M. R. A. Engel, and John C. Haltiwanger. Aggregate Employment Dynamics: Building from Microeconomic Evidence. American Economic Review, 87(1):115-137, 1997.

Ricardo J. Caballero, Kevin N. Cowan, Eduardo M.R.A. Engel, and Alejandro Micco. Effective Labor Regulation and Microeconomic Flexibility. Discussion Paper 1480, Cowles Foundation, September 2004.

Stijn Classens and Luc Laeven. Financial Development, Property Rights and Growth. Journal of Finance, 58(6):2401-2436, December 2003.

Steven J. Davis and John C. Haltiwanger. On the Driving Forces Behind Cyclical Movements in Employment and Job Reallocation. American Economic Review, 89(5):12341258, December 1999.

Steven J. Davis, John C. Haltiwanger, and Scott Schuh. Job Creation and Destruction. The MIT Press, Cambridge, Massachusetts, 1996. 260 pages.

Timothy Dunne, Mark J. Roberts, and Larry Samuelson. Patterns of Firm Entry and Exit in U.S. Manufacturing Industries. RAND Journal of Economics, 19(4):495-515, Winter 1988.

Timothy Dunne, Mark J. Roberts, and Larry Samuelson. Plant Turnover and Gross Employment Flows in the U.S. Manufacturing Plants. Journal of Labor Economics, 7(1): 48-71, January 1989.

EUROSTAT. Enterprises in Europe, Data 1994-95. Fifth Report of the Eropean Comission. EUROSTAT, Luxembourg, 1998.

Lucia Foster, John C. Haltiwanger, and C. J. Krizan. Aggregate Productivity Growth: Lessons from Microeconomic Evidence. In Edward Dean, Michael Harper, and Charles Hulten, editors, New Developments in Productivity Analysis. University of Chicago Press, 2001.

Lucia Foster, John C. Haltiwanger, and C. J. Krizan. The Link Between Aggregate and Micro Productivity Growth: Evidence from Retail Trade. Working Paper 9120, NBER, 2002.

Paul A. Geroski. Market Dynamics and Entry. Basil Blackwell, Oxford, UK; Cambridge, USA, 1991. 306 pages.

Paul A. Geroski. What do We Know about Entry. International Journal of Industrial Organization, 13:421-440, 1995. 
Zvi Griliches and Haim Regev. Firm Productivity in Israeli Industry 1979-1988. Econometrica, 65:175-203, 1995.

James Gwartney and Robert Lawson. Economic Freedom of the World. 2005 Annual Report. Fraser Institute, Vancouver, B.C., 2004.

John C. Haltiwanger, Stefano Scarpetta, and Milan Vodopivec. How Institutions Affect Labor Market Outcomes: Evidence from Transition Countries. Mimeo, April 2003.

John C. Haltiwanger, Stefano Scarpetta, and Helena Schweiger. Assessing Job Flows across Countries: The Role of Industry, Firm Size and Regulations. Discussion Paper 2450, IZA, 2006.

James J. Heckman and Carmen Pages, editors. Law and Employment: Lessons from Latin America and the Carribean. NBER Conference Series Report. University of Chicago Press, Chicago and London, 2004.

Hugo Hopenhayn and Richard Rogerson. Job Turnover and Policy Evaluation: A General Equilibrium Analysis. Journal of Political Economy, 101(5):915-938, 1993.

Boyan Jovanovic. Selection and the Evolution of Industry. Econometrica, 50(3):649-670, 1982.

David Kaufmann, Aart Kraay, and Massimo Mastruzzi. Governance Matters III: Governance Indicators for 1996, 1998, 2000, and 2002. World Bank Economic Review, 18: 253-287, 2004.

Leora Klapper, Luc Laeven, and Raghuram G. Rajan. Entry Regulation as a Barrier to Entrepreneurship. Journal of Financial Economics, 82(3):591-629, 2006.

Winfried Koeniger and Julien Prat. Employment Protection, Product Market Regulation and Firm Selection. Economic Journal, 117(521):302-322, 2007.

Adriana Kugler. The Effects of Employment Protection in Europe and the USA. Els Opuscles del CREI, (18):1-48, 2007.

Marc Melitz. The Impact of Trade on Intra-Industry Reallocation and Aggregate Industry Productivity. Econometrica, 71-6:1695-1725, 2003.

Julián Messina and Giovanna Vallanti. Job Flow Dynamics and Firing Restrictions: Evidence from Europe. Discussion Paper 2045, IZA, March 2006. 
Alejandro Micco and Carmen Pages. The Economic Effects of Employment Protection: Evidence from International Industry-Level Data. Discussion Paper 2433, IZA, November 2006.

Dale T. Mortensen and Christopher A. Pissarides. New Developments in Models of Search in the Labor Market. In Orley Ashenfelter and Richard Layard, editors, Handbook of Labor Economics, Vol. 3B. Handbooks in Economics, Vol. 5, pages 2567-2627. Elsevier Science, North Holland, Amsterdam, New York and Oxford, 1999a.

Dale T. Mortensen and Christopher A. Pissarides. Job Reallocation, Employment Fluctuations and Unemployment. In John B. Taylor and Michael Woodford, editors, Handbook of Macroeconomics, Vol. 1B. Handbooks in Economics, Vol. 15, pages 1171-1228. Elsevier Science, North Holland, Amsterdam, New York and Oxford, 1999b.

Stephen Nickell and Richard Layard. Labor Market Institutions and Eeconomic Performance. In Orley Ashenfelter and Richard Layard, editors, Handbook of Labor Economics, Vol. 3C. Handbooks in Economics, Vol. 5, pages 3029-3084. Elsevier Science, North Holland, Amsterdam, New York and Oxford, 1999.

Giuseppe Nicoletti and Stefano Scarpetta. Product Market Reforms and Employment in OECD Countries. OECD, Economics Department Working Paper 472, 2005.

G. Steven Olley and Ariel Pakes. The Dynamics of Productivity in the Telecommunications Equipment Industry. Econometrica, 64(6):1263-1297, 1996.

Ariel Pakes and Richard Ericson. Empirical Implications of Alternative Models of Firm Dynamics. Journal of Economic Theory, 79(1):1-45, 1998.

Raghuram G. Rajan and Luigi Zingales. Financial Dependence and Growth. American Economic Review, 88(3):559-586, June 1998.

John Sutton. Gibrat's Legacy. Journal of Economic Literature, 35(1):40-59, 1997. 
Table A.1: Data Sources Used for Firm Demographics and Job Flows

\begin{tabular}{|c|c|c|c|c|}
\hline Country & Source & Period & $\begin{array}{l}\text { Max. industry coverage } \\
\text { (number of industries) }\end{array}$ & Threshold \\
\hline \multicolumn{5}{|l|}{ OECD } \\
\hline Finland & Business register & $1988-1998$ & All (17) & $\begin{array}{l}\text { Emp } \geq 1 \\
\text { Turnover: }\end{array}$ \\
\hline France & Fiscal database & 1989-1997 & All (17) & $\begin{array}{l}\text { Man: Euro } 0.58 \mathrm{~m} \\
\text { Serv: Euro } 0.17 \mathrm{~m}\end{array}$ \\
\hline Germany (West) & Social security & 1977-1999 & $\begin{array}{l}\text { All but civil service, } \\
\text { self employed (11) }\end{array}$ & $\operatorname{Emp} \geq 1$ \\
\hline Italy & Social security & 1986-1994 & All (19) & $\operatorname{Emp} \geq 1$ \\
\hline Portugal & $\begin{array}{l}\text { Employment-based } \\
\text { register }\end{array}$ & 1983-1998 & $\begin{array}{l}\text { All but public } \\
\text { administration (19) }\end{array}$ & $\operatorname{Emp} \geq 1$ \\
\hline United Kingdom & Business register & $1980-1998$ & Manufacturing (10) & $\operatorname{Emp} \geq 1$ \\
\hline United States & Business register & 1988-1997 & Private businesses (19) & $\operatorname{Emp} \geq 1$ \\
\hline \multicolumn{5}{|l|}{ LAC } \\
\hline Argentina & $\begin{array}{l}\text { Register, based on Integrated } \\
\text { System of Pensions }\end{array}$ & 1995-2002 & All (19) & $\operatorname{Emp} \geq 1$ \\
\hline Brazil & Census & 1996-2001 & Manufacturing (13) & $\operatorname{Emp} \geq 1$ \\
\hline Chile & $\begin{array}{l}\text { Annual Industry } \\
\text { Survey (ENIA) }\end{array}$ & 1979-1999 & Manufacturing (13) & Emp. $\geq 10$ \\
\hline Colombia & $\begin{array}{l}\text { Annual Manufacturing } \\
\text { Survey (EAM) }\end{array}$ & $1982-1998$ & Manufacturing (13) & Emp. $\geq 10$ \\
\hline Mexico & Social security & $1985-2001$ & All (17) & $\operatorname{Emp} \geq 1$ \\
\hline \multicolumn{5}{|l|}{ TRANSITION } \\
\hline Estonia & Business register & $1995-2001$ & All (19) & $\operatorname{Emp} \geq 1$ \\
\hline Hungary & Fiscal register (APEH) & 1992-2001 & All (19) & $\operatorname{Emp} \geq 1$ \\
\hline Latvia & Business register & $1996-2002$ & All (18) & $\operatorname{Emp} \geq 1$ \\
\hline Slovenia & Business register & $1992-2001$ & All (19) & $\operatorname{Emp} \geq 1$ \\
\hline
\end{tabular}


Table B.1: Average Job Flows in the 1990s, Overall and by Region, Total Economy (Unbalanced Panel)

\begin{tabular}{|c|c|c|c|c|c|}
\hline \multicolumn{6}{|l|}{ OVERALL } \\
\hline Variable & Obs & Mean & Std. Dev. & Min & Max \\
\hline Job Creation Rate & 1048 & 0.147 & 0.067 & 0.000 & 0.647 \\
\hline Job Destruction Rate & 1048 & 0.131 & 0.062 & 0.000 & 0.419 \\
\hline Net Employment Growth & 1048 & 0.015 & 0.065 & -0.299 & 0.419 \\
\hline Job Reallocation Rate & 1048 & 0.278 & 0.112 & 0.000 & 0.875 \\
\hline Excess Job Reallocation Rate & 1048 & 0.231 & 0.098 & 0.000 & 0.732 \\
\hline Job Creation Rate (Entry) & 1048 & 0.055 & 0.043 & 0.000 & 0.357 \\
\hline Job Destruction Rate (Exit) & 1048 & 0.046 & 0.029 & 0.000 & 0.216 \\
\hline \multicolumn{6}{|l|}{ OECD } \\
\hline Job Creation Rate & 448 & 0.127 & 0.046 & 0.033 & 0.288 \\
\hline Job Destruction Rate & 448 & 0.127 & 0.060 & 0.029 & 0.411 \\
\hline Net Employment Growth & 448 & 0.000 & 0.046 & -0.282 & 0.148 \\
\hline Job Reallocation Rate & 448 & 0.254 & 0.096 & 0.072 & 0.57 \\
\hline Excess Job Reallocation Rate & 448 & 0.223 & 0.085 & 0.058 & 0.472 \\
\hline Job Creation Rate (Entry) & 448 & 0.045 & 0.030 & 0.003 & 0.195 \\
\hline Job Destruction Rate (Exit) & 448 & 0.045 & 0.028 & 0.000 & 0.216 \\
\hline \multicolumn{6}{|l|}{$\mathrm{LAC}$} \\
\hline Job Creation Rate & 300 & 0.148 & 0.061 & 0.033 & 0.431 \\
\hline Job Destruction Rate & 300 & 0.140 & 0.066 & 0.041 & 0.419 \\
\hline Net Employment Growth & 300 & 0.008 & 0.053 & -0.214 & 0.286 \\
\hline Job Reallocation Rate & 300 & 0.288 & 0.114 & 0.086 & 0.785 \\
\hline Excess Job Reallocation Rate & 300 & 0.248 & 0.103 & 0.066 & 0.732 \\
\hline Job Creation Rate (Entry) & 300 & 0.056 & 0.040 & 0.000 & 0.227 \\
\hline Job Destruction Rate (Exit) & 300 & 0.053 & 0.032 & 0.003 & 0.152 \\
\hline \multicolumn{6}{|l|}{ TRANSITION } \\
\hline Job Creation Rate & 300 & 0.174 & 0.088 & 0.000 & 0.647 \\
\hline Job Destruction Rate & 300 & 0.128 & 0.061 & 0.000 & 0.385 \\
\hline Net Employment Growth & 300 & 0.046 & 0.087 & -0.299 & 0.419 \\
\hline Job Reallocation Rate & 300 & 0.303 & 0.123 & 0.000 & 0.875 \\
\hline Excess Job Reallocation Rate & 300 & 0.227 & 0.109 & 0.000 & 0.608 \\
\hline Job Creation Rate (Entry) & 300 & 0.070 & 0.056 & 0.000 & 0.357 \\
\hline Job Destruction Rate (Exit) & 300 & 0.039 & 0.025 & 0.000 & 0.135 \\
\hline
\end{tabular}

Source: Own calculations based on harmonized firm-level database. 
Table C.1: Definitions of Institutional Variables

\begin{tabular}{|l|l|}
\hline \hline Variable & Definition \\
\hline Hiring and Firing Practices & $\begin{array}{l}\text { Flexibility in hiring and firing (5B(ii)) from Fraser Insti- } \\
\text { tute, hiring and firing practices of companies are deter- } \\
\text { mined by private contract (World Economic Forum: Global } \\
\text { Competitiveness Report); scale [0,10], 10 being the worst. }\end{array}$ \\
\hline Business Regulations & $\begin{array}{l}\text { Regulation of business activities (5c) from Fraser Institute } \\
\text { (World Economic Forum: Global Competitiveness Report); } \\
\text { scale [0,10], 10 being the worst. }\end{array}$ \\
\hline Law and Order & $\begin{array}{l}\text { Integrity of Legal System (2e) from Fraser Institute, which } \\
\text { is based on Political Risk Component I (Law and Order) } \\
\text { from the International Country Risk Guide; scale [0,10], 10 } \\
\text { being the worst. }\end{array}$ \\
\hline
\end{tabular}

Table C.2: Institutional Variables, 1990s

\begin{tabular}{lrrrr}
\hline \hline OVERALL & & & & \\
\hline Variable & Mean & Std. Dev. & Min & Max \\
\hline Hiring and Firing Practices & 5.261 & 1.515 & 2.878 & 7.700 \\
Law\&Order adj. Hiring and Firing Practices & 4.113 & 2.019 & 0.000 & 7.209 \\
Business Regulations & 3.490 & 1.389 & 1.100 & 5.900 \\
Law\&Order adj. Business Regulations & 2.490 & 1.233 & 0.000 & 4.600 \\
Law and Order & 2.280 & 2.818 & 0.000 & 10.000 \\
\hline EU \& USA & & & & \\
\hline Hiring and Firing Practices & 5.427 & 1.804 & 2.878 & 7.400 \\
Law\&Order adj. Hiring and Firing Practices & 5.084 & 1.559 & 2.878 & 6.600 \\
Business Regulations & 3.074 & 1.682 & 1.100 & 5.600 \\
Law\&Order adj. Business Regulations & 2.822 & 1.349 & 1.100 & 4.600 \\
Law and Order & 0.469 & 1.121 & 0.000 & 3.000 \\
\hline LAC & & & & \\
\hline Hiring and Firing Restrictions & 4.679 & 0.943 & 3.230 & 5.740 \\
Law\&Order adj. Hiring and Firing Restrictions & 2.249 & 1.642 & 0.000 & 4.431 \\
Business Regulations & 4.206 & 1.297 & 2.617 & 5.900 \\
Law\&Order adj. Business Regulations & 1.811 & 1.321 & 0.000 & 3.320 \\
Law and Order & 4.949 & 2.769 & 2.280 & 10.000 \\
\hline TRANSITION & & & & \\
\hline Hiring and Firing Restrictions & 5.696 & 1.705 & 3.586 & 7.700 \\
Law\&Order adj. Hiring and Firing Restrictions & 4.742 & 1.846 & 3.079 & 7.209 \\
Business Regulations & 3.323 & 0.669 & 2.650 & 4.200 \\
Law\&Order adj. Business Regulations & 2.757 & 0.716 & 1.776 & 3.486 \\
Law and Order & 1.763 & 1.119 & 0.637 & 3.300 \\
\hline
\end{tabular}

Source: Own calculations based on harmonized firm-level database and Gwartney and Lawson [2004]. 